\title{
Relationship between organisational commitment and effectiveness of human resource management practices in a South African information technology company
}

\begin{tabular}{|c|c|}
\hline \multicolumn{2}{|c|}{$\begin{array}{l}\text { Authors: } \\
\text { Lebogang N. Setsena }^{1} \text { (D) } \\
\text { Christian T. Botha }{ }^{1} \\
\text { Leigh-Anne Paul-Dachapalli }^{1}\end{array}$} \\
\hline \multicolumn{2}{|c|}{$\begin{array}{l}\text { Affiliations: } \\
{ }^{1} \text { Department of People } \\
\text { Management and } \\
\text { Development, Faculty of } \\
\text { Management Sciences, } \\
\text { Tshwane University of } \\
\text { Technology, Pretoria, } \\
\text { South Africa }\end{array}$} \\
\hline \multicolumn{2}{|c|}{$\begin{array}{l}\text { Corresponding author: } \\
\text { Lebogang Setsena, } \\
\text { lebogangsetsena@gmail.com }\end{array}$} \\
\hline \multicolumn{2}{|c|}{$\begin{array}{l}\text { Dates: } \\
\text { Received: } 27 \text { Feb. } 2021 \\
\text { Accepted: } 12 \text { May } 2021 \\
\text { Published: } 28 \text { July } 2021\end{array}$} \\
\hline \multicolumn{2}{|c|}{$\begin{array}{l}\text { How to cite this article: } \\
\text { Setsena, L.N., Botha, C.T., \& } \\
\text { Paul-Dachapalli, L-A. (2021). } \\
\text { Relationship between } \\
\text { organisational commitment } \\
\text { and effectiveness of human } \\
\text { resource management } \\
\text { practices in a South African } \\
\text { information technology } \\
\text { company. SA Journal of } \\
\text { Human Resource } \\
\text { Management/SA Tydskrif vir } \\
\text { Menslikehulpbronbestuur, } \\
\text { 19(0), a1586. https://doi. } \\
\text { org/10.4102/sajhrm. } \\
\text { v19i0.1586 }\end{array}$} \\
\hline \multicolumn{2}{|c|}{$\begin{array}{l}\text { Copyright: } \\
\text { (C) 2021. The Authors } \\
\text { Licensee: AOSIS. This } \\
\text { is licensed under the } \\
\text { Creative Commons } \\
\text { Attribution License. }\end{array}$} \\
\hline \multicolumn{2}{|l|}{ Read online: } \\
\hline 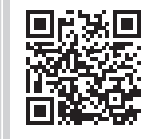 & $\begin{array}{l}\text { Scan this QR } \\
\text { code with your } \\
\text { smart phone or } \\
\text { mobile device } \\
\text { to read online. }\end{array}$ \\
\hline
\end{tabular}

Orientation: This article presents the characteristics associated with organisational commitment levels and the perception of the effectiveness of human resource $(\mathrm{HR})$ management practices in a South African information technology (IT) company.

Research purpose: The objective of this research was to investigate whether there was a significant positive relationship between organisational commitment levels and the effectiveness of HR management practices amongst employees within the IT company along the lines of age, gender, race, educational level and tenure.

Motivation for the study: Companies are becoming increasingly interested in the promotion of commitment amongst employees because of the numerous benefits associated with organisational commitment, such as improved employee performance and reduced employee turnover.

Research approach/design and method: A quantitative research approach was used and a structured questionnaire, validated from previous studies, consisting of close-ended questions was used. A convenience sampling was used and a sample size of 309 participants was used to collect necessary data. Data were collected and analysed using the Stata V15 statistical analysis software. The results were interpreted with frequencies and percentages using tables and figures.

Main findings: The results indicated that a positive relationship between organisational commitment and HR management practices exist. In terms of variables, demographical groups vary.

Practical/managerial implications: Mangers need to understand employees' perceptions and attitudes towards the HR management practices employed in the organisation to determine whether these particular HR management practices achieve desirable outcomes.

Contribution/value-add: This study will contribute to an in-depth understanding of the effectiveness of HR management practices in managing the high turnover in organisations and to improve employee commitment in South African IT companies.

Keywords: organisational commitment; affective commitment; continuance commitment; normative commitment; human resource management practices.

\section{Introduction}

\section{Main focus of the study}

The effectiveness of human resource (HR) management on organisational commitment has been a key area of research in the past years, and several studies showed that a positive relationship existsbetween HRmanagement practicesand organisational commitment(Şendoğdu,Kocabacak, \& Güven, 2013, p. 819). This study is therefore conducted to investigate the relationship between organisational commitment and perceived effectiveness of HR management practices in a South African information technology (IT) company. Furthermore, it is hoped that this study will contribute to an in-depth understanding of the effectiveness of HR management practices in managing the turnover in organisations and to improve employee commitment in South African IT companies.

\section{Background and contextualisation of the study}

In South Africa, insufficient research is available specific to IT industry employees. Research has shown that IT employees appear to have strong tendencies to leave their organisations (Latchigadu, 
2016, p. 34). The company is a leading global professional services company, providing a broad range of IT solutions. The major challenge is that the company referred in this study has failed to maintain lower employee turnover rates in the past 3 years. On average, 15 employees leave the organisation per month. The highest number of resignations was recorded during the fiscal year 2018 when 49 employees resigned encompassing of 24 (48.98\%) female employees and 25 male employees (51.02\%). This becomes a major concern because IT employees have specialised skills and are difficult to replace (Van Dyk \& Coetzee, 2012, p. 1). Most of the company's money is spent on training and improving workers in their fields of expertise, and therefore losing employees with critical skills is a major issue. In the past, employees were searching for a better firm but in this era, companies are striving hard to attract, retain and increase employee commitment (Hassan \& Mahmood, 2016, p. 23).

\section{Literature review \\ Organisational commitment}

This study used Meyer and Allen's three-component model in a quest to examine the various ways on how organisational commitment evolves and affects employee behaviour in the workplace. The three-component model stems from three distinct perspectives, namely affective commitment (emotional attachment), continuance commitment (cost) and normative commitment (responsibility) (Meyer \& Allen, 1991).

Affective commitment refers to the emotional relationship that employees develop towards their organisation (Mabaso, 2017, p. 99). Research consistently shows that employees who are committed affectively will remain with the organisation because they desire to stay (Coetzee, Mitonga-Monga, \& Swart, 2014; Mitonga-Monga \& Flotman, 2017). Ferreira (2012, p. 3) researched that employees with affective commitment show emotional attitudes towards the organisation. They also have strong emotions and the desire to support the organisation's goals and values (Naik, 2012, p. 30).

Continuance commitment is theorised as the employees' awareness and acknowledgement of the costs and consequences associated with leaving the organisation (Ferreira, 2012, p. 3). Employees continue to work for an organisation because employee cannot afford to leave (Greenberg \& Baron, 2003, p. 162). Becker (1960) found that employees who show continuance commitment rather stay with the organisation than to lose the investments they have accumulated throughout the years. Nkomo's (2013, p. 71) research indicates that this attitude occurs when employees are aware that there are lack of job alternatives available to them.

Researchers Meyer and Allen (1991, p. 67) refer to normative commitment as an emotion of obligation to remain with the organisation and continue employment. Muleya (2017, p. 16) reports that normative commitment occurs when employees remain with the organisation because of an indebted obligation. Ndjama's (2015, p. 37) study indicates that normative commitment is influenced by social norms regarding the extent to which employees are or ought to be committed to their organisation. Cohen (2007, p. 343) states that these employees strongly believe that it is ethical to be loyal to their organisation. For instance, Tojari, Esmaeili and Majedi (2013, p. 165) found that when organisations train and invest in their employees, they might feel obligated to remain and repay the organisation by being loyal to their organisation. Mabaso's (2017, p. 100) study indicates that these obligatory feelings are based on employees' appreciation for incentives they have received from the organisation, in terms of training and development.

\section{Human resource management practices}

Human resource management practices are considered to be one of the major factors influencing organisational commitment, which, in turn, may lead to the production of desired organisational outcomes (Balgobind, 2007; Coetzee et al., 2014; Laka-Mathebula, 2004). The question therefore arises as to which HR management practices lead to improved organisational effectiveness. Research consistently shows that managers need to implement HR management practices that mould employees' behaviours and attitudes to improve favourable outcomes and performances (Obeidat, Masa'deh, \& Abdallah, 2014, p. 10). Tan and Nasurdin (2011, p. 157) view HR management practice as a system that motivates, attracts, retains and develops workers to ensure the effective implementation and the survival of the organisation and its employees.

Coetzee et al. (2014, p. 3) state that HR management practices may also be regarded as systems and processes aimed at improving the organisation's effectiveness and performance. Coetzee et al.'s (2014) study further uncovered 13 critical HR management practices that South African organisations need to consider to achieve favourable outcomes and high performance. Human resource management practices have therefore become essential in gaining a competitive advantage. These organisational HR practices were labelled as change management, communication, diversity and transformation, HR policies and procedures, innovation, job satisfaction, leadership, management style, performance, recognition, rewards and remuneration, training and development, and values and culture.

A study by Guchait (2007) uncovered eight effective HR management practices that affect employee commitment, and these HR management practices are relevant to the present study and include: training and development, performance appraisal, staffing, rewards, benefits, equal employment opportunities, good and safe working conditions and information sharing.

Each of these HR management practices is discussed below.

Training and development refers to the learning process that is aimed at helping employees to acquire and reinforce their 
skills, knowledge, experience and attitudes that employees need to perform their tasks efficiently and effectively to achieve the organisational goals (Tsere, 2015, p. 6). Although the present study is based in an IT services company, Dockel, Basson and Coetzee (2006, p. 22) highlight that it is significantly important to train employees on the latest technologies. This is to ensure that employees are well equipped with current and future skills that are demanded within the IT industry. Dockel et al.'s (2006, p. 22) study further indicates that employees feel valued after the organisation has invested in them through training, in turn, their affective commitment grows.

Performance appraisal refers to a systematic process for enhancing organisational performance by improving current and future performance of employees (Armstrong, 2006, p. 495). Shayo (2013, p. 9) reports that performance appraisal significantly contributes to the effectiveness of HR management because it is associated with organisational performance. Performance appraisal is important because it appears to be a crucial part of any HR management system (Farrell, 2013, p. 8).

Staffing is a critical HR management practice and that this process unquestionably plays a vital role in helping the organisation sustaining competitive advantage (Brock \& Buckley, 2013, p. 272). George (2014, p. 13) views staffing as a process of attracting most suitable job applicants who have the skills, knowledge and abilities required to help the organisation achieve its goals and objectives. Coetzee and Schreuder (2010, p. 71) highlight that the importance of staffing is hiring talented and qualified employees with critical and scarce skills to help the organisation to remain competitive in the globalised business environment.

Rewards are the key factors that retain and attract the best employees, more especially when employees are demotivated or have many job alternatives (Mabaso, 2015, p. 28). Rewards are classified into two groups, namely extrinsic and intrinsic rewards. According to Mabaso (2015, p. 28), extrinsic rewards are payoffs that organisations grant employees such as promotion, recognition, money and benefits, whereas intrinsic rewards are payoffs that are internally experienced and self-granted such as self-actualisation, self-esteem and a sense of accomplishment. This means that rewards play an important role by helping organisations to strengthen anticipated current and future performance.

Researchers Coffie, Boateng and Coffie (2018, p. 173) found that a significant relationship between rewards and organisational commitment exists. Meyer and Smith (2000, p. 321) highlight that the ability of a company's rewards practices to achieve emotional and normative commitment was largely influenced by the perceptions of procedural justice associated with the implementation of this factor.

Benefits can be viewed as indirect forms of the organisation's rewards intended to help with the attainment of the HR management objectives of motivating, attracting and retaining employees (Swanepoel, Erasmus, Schenk, \& Tshilongamulenzhe, 2014, p. 664). Similarly, Mabaso's (2015, p. 13) study indicates that benefits are significant characteristics that organisations use to motivate, attract and retain talented employees. These benefits may be in a form of health club affiliation, relocating expenses, education fees, car and cell phone allowance (Martocchio, 2013, p. 6).

Good and safe working conditions refer to the degree to which an organisation provides employees with satisfactory work hours, safe working facilities, autonomy, workloads and rest pauses, which are all determinants of the employee's retention, job satisfaction and organisational commitment (Mabaso, 2017, p. 82). He added the provision of good and safe working conditions in the workplace should be top priority in every organisation regardless of the type of services they offer or industry.

A study by Mrara (2010) found that providing good and safe working conditions to employee's is significant in determining whether employees' intentions are to stay with or leave the organisation. When employees feel that the employer offers them pleasant working conditions such as clean working environments, adequate equipment and tools, employees will find it easy to perform their jobs (Peete, 2016, p. 22). Contrary, when employees experience poor work and less satisfactory conditions in terms of noisy, unhygienic and facilities that lack ventilation, employees tend to be demotivated to get their work done (Mabaso, 2015, p. 31). This implies that employees enjoy working under good and safe conditions, where they feel important and valued, they put in more effort to help the organisation to achieve its objectives (Fauzi, Ahmad, \& Gelaidan, 2013, p. 646). Hence, Mabaso (2015, p. 29) concluded that good and safe working conditions play a significant role as a motivating factor for employees' satisfaction and commitment.

Equal employment opportunity is one of the most crucial HR management practice in organisations (Peete, 2018, p. 61). Kola's (2012) study indicates that the South African government implemented a strategy known as affirmative action and subsequently introduced the Employment Equity Act to redress the inequities caused by the apartheid era, where some employees were given more opportunities than their counterparts.

For many years, researchers have been interested in the relationship between sharing of information and organisational commitment (Laka-Mathebula, 2004; Meyer \& Allen, 1991). Information sharing includes transparent HR policies and procedures (Coetzee et al., 2014, p. 8). According to Coffie et al. (2018, p. 174), information sharing ensures that employees are recognised in the decision-making process of the organisation and sends a signal to the employees that management respects their opinions and values their participation. This provides employees the assurance that the organisation values them and subsequently grows their affective commitment (Meyer \& Allen, 1991, p. 62). 


\section{Research design Research approach}

A quantitative survey design approach was used to achieve the objectives of the study. The research approach can be described as a cross-sectional field survey, where data were collected at one point in time. The design is suitable to study the relationship between the different variables of organisational commitment and HR management practices. Questionnaires were used to collect primary data and data analysis used was both descriptive and inferential statistics.

\section{Research method}

\section{Research participants}

The population consisted of 1500 employees in an IT company in South Africa and a sample of 309 was used. A convenience sampling was used. The participants who took part in this study in terms of demographics were $25.89 \%$ male participants and $74.11 \%$ female participants. In terms of race, $91.59 \%$ were black people, and $8.41 \%$ were white people. Most of the participants were aged between 22 and 29 $(85.44 \%)$ and 30 and $39(10.36 \%)$, and less participants were between the ages of 40 and $65(4.20 \%)$. Most of the participants were single (89.97\%) and married $(7.77 \%)$, and less participants were divorced and widowed (2.26\%). With regard to educational level, participants who held a higher certificate equivalent to grade 12 constituted $7.12 \%$ of the sample. The lowest percentage $(3.24 \%)$ of participants possessed diplomas and advanced certificates. The majority of the participants $52.43 \%$ possessed a degree and advanced diploma this is followed by $30.42 \%$ participants that possess postgraduate degree. Whilst $6.80 \%$ of participants possessed other qualifications. In terms of tenure, participants who completed the questionnaire had a tenure of service between 0 to 1 year comprised $61.17 \%$ between 2 and 5 years of tenure, $2.27 \%$ between 6 and 9 years of tenure, $1.29 \%$ between 10 and 15 years of tenure and $0.65 \%$ had 16 to 25 years of tenure. The majority of participants $(70.87 \%)$ were employed at analyst level, followed by the other category, which constituted $19.74 \%$ of participants, whilst senior analyst represented $3.56 \%$. The smallest participants were employed at associate manager level with $3.24 \%$ and managers with $2.59 \%$.

\section{Measuring instruments}

Two measuring instruments were used in this study. To measure employees' level of commitment, the Organisational Commitment Questionnaire (OCQ) (Meyer \& Allen, 1991) was used. The OCQ is used to measure employees' affective commitment (eight items), continuance commitment (eight items) and normative commitment (eight items). A five-point Likert scale ranging from 1 (strongly disagree) to 5 (strongly agree) was used. With regard to internal consistency, Meyer and Allen (1997) reported the following Cronbach's alpha coefficients: affective (0.85), continuance (0.79) and normative commitment (0.73). Although Meyer and Allen (1997) Cronbach's alpha coefficients findings were higher than 0.70 , this study yielded acceptable Cronbach's alpha coefficients: affective (0.53), continuance (0.66) and normative commitment (0.69). The researchers decided to follow Bryman and Bell's (2007, p. 164) recommendation of 0.50 that would be an acceptable threshold for an acceptable alpha score for this study.

The Human Resource Management Practices Questionnaire (HRMPQ) which was well- established by (Guchait, 2007) was used to measure employees' perceptions regarding eight organisational HR practices. These practices are seen to affect employee commitment and are therefore deemed to be important for creating Job satisfaction. The HRMPQ that consists of 32 items measured on a five-point Likert scale ranging from 1 (strongly disagree) to 5 (strongly agree) was used. Originally, the HRMPQ instrument consists of 42 items; however, for this particular study, only 32 items were used. With regard to internal consistency, Guchait (2007:32) reported the following Cronbach's alpha coefficients: training and development (0.82), performance appraisal (0.79), staffing (0.69), rewards (0.91), benefits (0.71), equal employment opportunities (0.78), good and safe working conditions (0.75) and information sharing (0.86). The present study yielded practically acceptable internal consistency reliabilities: training and development (0.83), performance appraisal (0.83), staffing (0.73), rewards (0.65), benefits (0.54), equal employment opportunities (0.78), good and safe working conditions (0.84), and information sharing (0.73).

\section{Research procedure}

With regard to ethical considerations, the management at the IT company of interest was approached and permission was granted to conduct the study. Ethical clearance was issued by the research committee. An informed consent form was completed by the participants and by completing and returning the consent forms and questionnaires indicated that they had granted permission for their responses to the questionnaires to be utilised for the purpose of the study. Participation was optional and the confidentiality of the participants was sustained.

\section{Ethical considerations}

This article followed all ethical standards for a research with direct contact with human or animal subjects.

\section{Results}

The Stata version 15 statistical analysis software was used for the analysis of data. Descriptive statistics were reported in a form of frequencies and percentages. In terms of inferential statistics, the structural equation modelling (SEM) using the partial least squares path modelling approach (PLS-PM) was performed. Bootstrapping was used to estimate the parameters and associated standard errors in the direct and indirect effect in the statistical analysis of the structural equation model through the non-parametric method. Pearson's Chi-square test with a recommended and 
acceptable cut-off point of 0.05 was applied. If the $p$-value is less than 0.05, a significant relationship exists and if the $p$-value is greater than 0.05 , a significant relationship does not exist (Field, 2009).

\section{Descriptive statistics Respondents}

The research site was situated in an IT company in Gauteng, South Africa. A total of 309 respondents participated in the study, and the response rate was $100 \%$. The data presented in Table 1 show more female participants (74.11\%) than male participants $(25.89 \%)$ who participated in the study. The data show that most respondents were African with $86.41 \%$, followed by their white counterparts with $8.41 \%$. Mixed races represented $3.56 \%$ and the remaining $1.62 \%$ represented Indian participants. The majority of the respondents (85.44\%) were between the ages of 22 and 29 years. With regard to the education of the respondents, the majority of the respondents (52.43\%) have degrees and advanced diplomas. In terms of tenure, the data show that $34.63 \%$ of the respondents who completed the questionnaire had a tenure of service between 0 and 1 year, $61.17 \%$ between 2 and 5 years of service, 2.27\% between 6 and 9 years of service, $1.29 \%$ between 10 and 15 years of service and $0.65 \%$ had between 16 and 25 years of service.

\section{Pearson's Chi-square test of significance}

The Chi-square test was applied to all 24 OCQ questionnaires and the different groups of the biographical variables, namely gender, race age, level of education and years of service. The interpretation was performed at alpha value of 0.05 . Thus, the association was declared significant if the $p$-value was found to be less than 0.05 (Field, 2009, p. 688). The association between biographical variables and organisational commitment is explained below.

TABLE 1: Characteristics of participants.

\begin{tabular}{llcc}
\hline Variable & Category & Frequency & \% \\
\hline Gender & Male & 80 & 25.89 \\
& Female & 229 & 74.11 \\
Race & Black people & 283 & 91.59 \\
& White people & 26 & 8.41 \\
Age (in years) & $22-29$ & 264 & 85.44 \\
& $30-39$ & 32 & 10.36 \\
& $40-49$ & 10 & 3.24 \\
& $50-65$ & 3 & 0.97 \\
Educational level & Higher certificate (NQF-5) & 22 & 7.12 \\
& Diploma or advanced certificate (NQF-6) & 10 & 3.24 \\
& Degree or advanced diploma (NQF-7) & 162 & 52.43 \\
& Postgraduate (NQF-8-10) & 94 & 30.42 \\
\hline \multirow{2}{*}{ Tenure (in years) } & Less than 1 & 107 & 34.63 \\
& $2-5$ & 189 & 61.17 \\
& $6-9$ & 7 & 2.27 \\
& $10-15$ & 4 & 1.29 \\
& $16-25$ & 2 & 0.65 \\
\hline
\end{tabular}

Source: Setsena, L.N. (2020). Relationship between organisational commitment levels and effectiveness of human resource management practices in South African IT company. M Tech, Dissertation, Pretoria: Tshwane University of Technology.

NQF, national qualifications framework.
The computed significance values of gender and the eight dimensions of affective commitment were greater than 0.05 . Hence, it is concluded that there is no significant association between gender and each dimension of affective commitment. This implies that the participants are not emotionally attached to their organisation. With regard to gender and continuance commitment, the results showed that a statistically significant association $(p=0.017)$ exists between the gender of the participants and the continuance commitment dimension for 'Staying with my organisation is a matter of necessity as much as desire'. This implies that gender influences the importance that employees attached to staying with their organisation are a matter of necessity as much as desire. The present study yielded that the computed significance values of the relationship between gender and the eight dimensions of normative commitment were greater than the acceptable value of 0.05 . Hence, it was concluded that there is no significant relationship between gender and each dimension of normative commitment. The present study yielded that gender is strongly associated with continuance and normative commitment.

With regard to race and affective commitment, the results show that a statistically significant association $(p=0.018)$ exists between the race of the participants and the affective commitment dimension for 'I think that I could easily become as attached to another organisation as I am to this one'. The results also reported that a statistically significant association ( $p=0.024$ ) exists between the race of the participants and the affective commitment dimension for 'I do not feel a strong sense of belonging to my organisation'. The present study indicated that a statistically significant association $(p=0.004)$ exists between the race of the respondents and the continuance commitment dimension: 'It would be very hard for me to leave my organisation right now, even if I wanted to'. The results also show that a statistically significant association $(p=0.002)$ exists between the race of the respondents and the continuance commitment dimension: 'It would not be too costly for me to leave my organisation now'. The results further show that a statistically significant association $(p=0.027)$ exists between the race of the respondents and continuance commitment dimension: 'Staying with my organisation is a matter of necessity as much as desire'. The other dimensions of continuance commitment did not have a statistically significant relationship with race. Furthermore, the present study showed that a statistically significant association $(p=0.014)$ exists between the race of the respondents and normative commitment dimension: 'Jumping from organisation to organisation does not seem at all unethical to me'. The results further show that a statistically significant association ( $p=$ 0.049 ) exists between the race of the respondents and normative commitment dimension: 'I was taught to believe in the value of remaining loyal to one organisation'. The other dimensions of normative commitment did not have a statistically significant relationship with race. The study reported that all organisational levels had a positive relationship with participants' race. 
With regard to age and affective commitment, the results showed that a statistically significant association $(p=0.026)$ exists between the age of the respondents and affective commitment dimension: 'I do not feel like part of the family at my organisation'. The results also show that a statistically significant association $(p=0.030)$ exists between the age of the respondents and affective commitment dimension: 'I do not feel emotionally attached to this organisation'. The other dimensions of affective commitment did not have a statistically significant relationship with age. The results showed that a statistically significant association $(p=0.044)$ exists between the age of the respondents and continuance commitment dimension: 'I am not afraid of what might happen if I quit my job without having another one lined up'. The other dimensions of continuance commitment did not have a statistically significant relationship with age. Furthermore, the results reported that the computed significance values of the relationship between age and the eight dimensions of normative commitment are greater than the acceptable value of 0.05 . Therefore, it is concluded that there is no significant relationship between age and each dimension of normative commitment. The present study yielded that participants' age was strongly associated with affective and continuance commitment.

The results showed that the computed significance values of the relationship between the educational level of the respondents and the eight dimensions of affective commitment are greater than the acceptable value of 0.05 . Therefore, it is concluded that there is no significant relationship between education and each dimension of affective commitment. With regard to continuance commitment, a statistically significant association exists between items B10 with a $p$-value of 0.005: 'It would be very hard for me to leave my organisation right now, even if I wanted to'. As well as B13 with a $p$-value of 0.010: 'Staying with my organisation is a matter of necessity as much as desire'. In addition, the results showed that a statistically significant association ( $p=0.001)$ exists between the educational level of the respondents and the normative commitment dimension for 'I do not believe that a person must always be loyal to his or her organisation'. Though, the other dimensions of normative commitment did not have a statistically significant relationship with education. The present study yielded that participants' educational level was strongly associated with affective and continuance commitment.

The results reported that the computed significance values of the relationship between position and the eight dimensions of affective commitment are greater than the acceptable value of 0.05 . Therefore, it is concluded that there is no significant relationship between position and each dimension of affective commitment. With regard to continuance commitment, a statistically significant association $(p=0.014)$ exists between the position held respondents and the continuance commitment dimension B10: 'It would be very hard for me to leave my organisation right now, even if I wanted to'. The results also show that a statistically significant association (B13: $p=0.036$ and B14: $p=0.048$ ) exists between the educational level of the respondents and the continuance commitment dimension.

With regard to tenure, the results showed that a statistically significant association $(p=0.030)$ exists between the years of service of the respondents and the affective commitment dimension: 'I enjoy discussing my organisation with people outside it'. The results also showed that a statistically significant association $(p=0.002)$ exists between the years of service of the respondents and the continuance commitment dimension: 'Staying with my organisation is a matter of necessity as much as desire'. Furthermore, it was reported that a statistically significant association $(p=0.012)$ exists between the years of service of the respondents and the normative commitment dimension: 'I was taught to believe in the value of remaining loyal to one organisation'. However, the other dimensions of normative commitment did not have a statistically significant relationship with years of service worked at the organisation. The study reported that all organisational levels had a positive relationship with participants' tenure.

\section{Measurement model evaluation}

Structural equation modelling process consists of two parts, namely the measurement model evaluation and the testing of the structural model. Measurement model evaluation is intended to evaluate the validity and consistency of the manifest variables. Validity of the variables is tested based on convergent and discriminant validity, and individual manifest reliability explains the variance of individual manifest relative to latent variable by calculating standardised outer loadings of the manifest variable, whilst, consistency evaluations are through individual manifest and construct reliability tests.

\section{Factor and reliability analysis}

The results presented in Table 2 showed that the Cronbach's alpha values for all the variables are between the cut-off point of 0.5 and 0.7. The Dillon-Goldstein's rho for all the variables was above 0.7 that indicates homogeneity of the factor. The results suggest that all the variables are reliable

TABLE 2: Final model: Revised assessment of the internal consistency.

\begin{tabular}{lcccc}
\hline Variables & $\begin{array}{c}\text { Number of } \\
\text { items }\end{array}$ & $\begin{array}{c}\text { Cronbach's } \\
\text { alpha }\end{array}$ & $\begin{array}{c}\text { Composite } \\
\text { reliability }\end{array}$ & AVE \\
\hline Affective commitment & 3 & 0.53 & 0.76 & 0.5236422 \\
Continuance commitment & 5 & 0.66 & 0.79 & 0.396728 \\
Normative commitment & 3 & 0.69 & 0.83 & 0.6135798 \\
Training and development & 4 & 0.83 & 0.889 & 0.668684 \\
Performance appraisal & 4 & 0.83 & 0.88 & 0.6659028 \\
Staffing & 3 & 0.73 & 0.84 & 0.6499393 \\
Rewards & 3 & 0.65 & 0.79 & 0.4863509 \\
Information sharing & 4 & 0.73 & 0.83 & 0.5549939 \\
$\begin{array}{l}\text { Equal employment } \\
\text { opportunities }\end{array}$ & 4 & 0.78 & 0.86 & 0.6057454 \\
Benefits & 3 & 0.54 & 0.76 & 0.52651 \\
$\begin{array}{l}\text { Good and safe working } \\
\text { conditions }\end{array}$ & 4 & 0.84 & 0.89 & 0.6846565 \\
\hline
\end{tabular}

Source: Setsena, L.N. (2020). Relationship between organisational commitment levels and effectiveness of human resource management practices in South African IT company. M Tech, Dissertation, Pretoria: Tshwane University of Technology.

$\mathrm{AVE}$, average variance extracted. 
with regard to internal consistency. The quality of a measurement model was examined by testing the convergent validity, which shows the degree to which the indicators under the constructs are related. Convergent validity shows the amount of variance the indicators have in common: high factor loading and average variance extracted (AVE). According to Hair, Black, Babin and Anderson (2014, p. 107), AVE loadings above 0.5 are indicators of convergent validity. The results displayed in Table 2 indicate that the AVE loadings were above 0.5 , except for continuance commitment with 0.3 . The final model factor loadings are also reported in Table 2.

\section{Structural equation model results}

Only variables that showed a positive significant relationship were reported. The results presented in Figure 1 show that there is a positive significant relationship between training and development and normative commitment, $\beta=0.217$ and confidence interval (CI) $(0.062,0.382)$. The results show that performance appraisal has a significant positive effect on normative commitment with $\beta=0.276$ and CI $(0.956,0.439)$. The results further show that there is a positive significant relationship between staffing and continuance commitment $\beta=0.161$ and $C I(0.006,0.338)$. With regard to information sharing and affective commitment, a positive significant relationship with $\beta=-0.190$ and $\mathrm{CI}(-0.333,-0.068)$ exists. The results also reported that there is a positive significant relationship between benefits and normative commitment, $\beta=0.118$ and CI $(0.004,0.246)$. Figure 1 also shows a positive significant relationship between good and safe working conditions and affective commitment with $\beta=-0.292$ and CI $(-0.420,-0.140)$ exists. Similarly, the results indicate a positive significant relationship between good and safe working

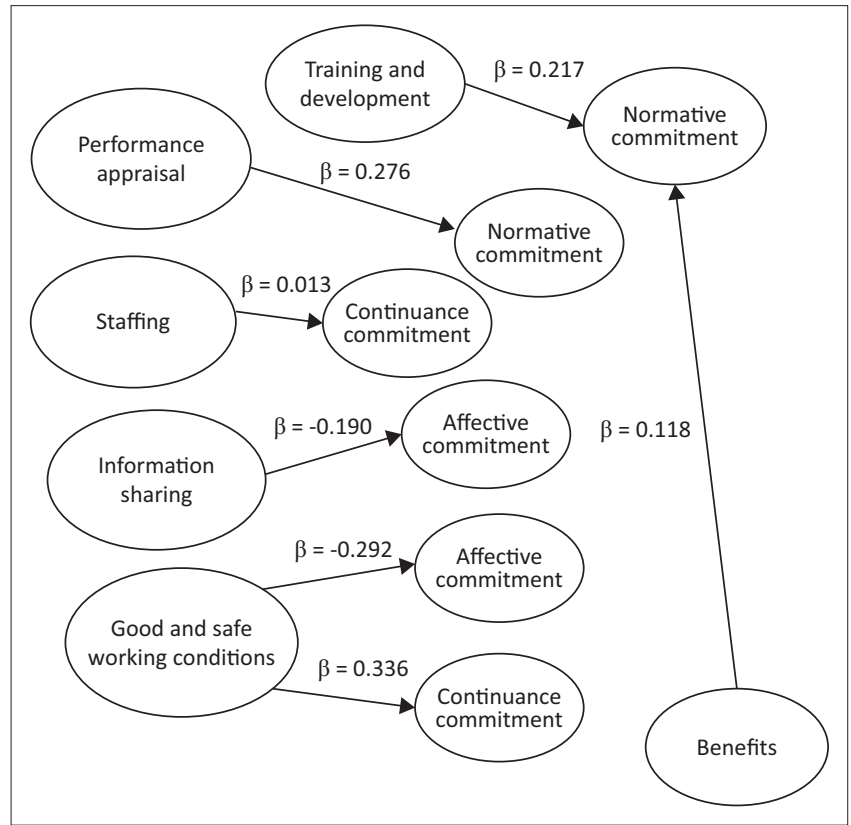

Source: Setsena, L.N. (2020). Relationship between organisational commitment levels and effectiveness of human resource management practices in South African IT company. M Tech, Dissertation, Pretoria: Tshwane University of Technology.

FIGURE 1: Structural model relationship between organisational commitment and human resource management practices. conditions and continuance commitment with $\beta=0.336$ and CI $(0.160,0.476)$.

\section{Discussion}

This study contributes to the empirical research that Coetzee et al. (2014), Van Dyk and Coetzee (2012), Coetzee and Botha (2012), Laka-Mathebula (2004) and Dockel (2003) conducted in the South African perspective. Researchers have conducted previous research to investigate the relationship between organisational commitment and job satisfaction on employee performance and retention in South Africa. However, not much has been done to investigate the HR management practices that have a major influence on employee commitment in IT organisations. This study is one of the few that investigated the impact of organisational commitment levels and the effectiveness of HR management practices in a South African IT company. Therefore, this study's results are anticipated to contribute to the existing literature on organisational commitment and HR management practices and to provide references to IT organisations in South Africa.

\section{Outline of the results \\ Demographics and organisational commitment levels}

With regard to gender, the present study showed that a positive relationship exists between continuance and normative commitment and participants' gender. The results are in agreement with the findings of Khalili and Asmawi (2012). They reported that gender is positively associated with continuance commitment. However, the present study contradicts the findings of Van Dyk and Coetzee (2012). They showed that men seemed to have a significant relationship than their women counterparts on affective commitment. According to Thabane (2016, p. 39), early research shows that gender's impact on organisational commitment has produced inconsistent results. Research performed by Mathieu and Zajac (1990) showed that female participants are affectively committed more to the organisation than men, whereas research by Ngo and Tsang (1998) showed no positive relationship between gender and organisational commitment. Initially, the works of Wahn (1998) highlighted that female participants are more affectively committed to the organisation than men. Whilst a lot of evidence points to this conclusion, there should be a consideration that female participants have fewer employment opportunities than their counterparts.

With regard to race, black participants were found to be more committed than their white counterparts. The results are consistent with Martin and Roodt (2008) and Clinton-Baker (2013); their results showed that black participants were more positive about their commitment to the organisation than white participants. Opposingly, research performed by Coetzee and Schreuder (2010) reported that black managers seemed to have lower commitment levels compared to white managers. Coetzee and Botha (2012) reported that opposing findings on whether ethnicity affect organisational 
commitment that may be a result of differences in the conceptualisation of commitment.

With regard to age, the present study reported that age had a statistically significant relationship with affective and continuance commitment. The findings appear to support that of Laka-Mathebula (2004). The study reported that age is positively associated with organisational commitment. Bull (2005) found that younger employees have lower levels of commitment towards their organisation. Peete's (2016) study found that older employees have high levels of commitment because of investment they have accumulated over the years with their organisation.

The present study yielded that participants' educational level was strongly associated with affective and continuance commitment. Joiner and Bakalis' (2006) study found that an employee's educational level is positively related to organisational commitment. Contrary, Kargar's (2012) study found no positive relationship between employees' educational level and organisational commitment. If employees' levels of education increase, their level of commitment will decrease (Martin \& Roodt, 2008, p. 29). Employees with high levels of education are exposed to more alternative opportunities of employment than employees with less qualifications (Kelly, 2015, p. 34). The present study yielded that participants' position is strongly associated with continuance and normative commitment.

With regard to tenure, the study reported that all organisational levels had a positive relationship with participants' tenure. The findings also seem to corroborate the study of Anari (2012). The study showed that participants' years of service are positively associated with organisational commitment. Van Dyk's (2011) study found that employees with longer than 11 years and above are significantly associated with affective and normative commitment.

\section{The relationship between organisational commitment and human resource management practices}

According to the results, training and development has a strong, significant relation to normative commitment. Literature shows that employees with normative commitment reflect feelings of obligation to stay with an organisation. Employees feel that they need to stay with an organisation because it paid for their training and development. The result corroborates the finding of Coetzee et al. (2014)., which was significantly related to normative commitment. Martin (2011. p. 37) argues that training is a significant component attributing to high levels of organisational commitment. His study further reveals that the employee's commitment levels increase subsequent to training. In addition, Martin (2011, p. 37) reveals that the employee's commitment and motivation for training is strongly positive. Therefore, it is important for organisations to gain a competitive advantage using different training and development methods and, ultimately, assisting employees to acquire new skills and knowledge. Managers should invest more in training and developing employees because the organisation is an IT organisation and technology is rapidly changing, and this will help reinforce employees' current and future skills, which will be required by the organisation and employees to perform their duties efficiently.

Performance appraisal has a strong significant relation with normative commitment. Contrary, Laka-Mathebula (2004) found that the relationship between performance appraisal and organisational commitment is not very clear. If a company offers high-quality performance appraisal experience, it is likely to improve the perceived company obligations of the employees, which in turn could impact their attitudes and potentially their behaviours (Mopalami, 2015 , p. 35). Therefore, it is highly recommended that managers should appraise employees fairly and equally.

According to the findings of this study, staffing has a significant positive relation with continuance commitment. Staffing is a critical HR management practice and that this process unquestionably plays a vital role in helping the organisation sustain competitive advantage (Brock \& Buckley, 2013, p. 272). The findings of the present study are corroborated by Coffie et al. (2018). They found that staffing has a significant positive relation with continuance commitment. Managers should refrain from hiring people based on favouritism, but should employ talented and qualified employees to assist the organisation to achieve its current and future goals.

With regard to rewards, the present study finding showed that rewards had no significant positive relation with affective, continuance and normative commitment. The findings contradict that of Coffie et al. (2018). They found that a signification relationship between rewards and organisational commitment exists. Furthermore, research performed by Laka-Mathebula (2004) found that reward systems, such as a higher wage base, share of earnings, bonuses and stock options for employees, act as incentives for employees to commit to organisational goals. It is therefore recommended that managers need to provide IT professional with such rewards. Dockel's (2003) findings are in agreement by revealing that high technology employees want a competitive salary.

The findings of the present study showed that information sharing had a significant positive relation with affective commitment. The results corroborate that of Meyer and Smith (2009). They reported that the sharing of information is positively correlated with affective commitment by building the trust of managers and the self-worth of workers. Coetzee et al. (2014) agree by suggesting that information such as HR policies and procedures should be conveniently available to everyone in the organisation.

With regard to equal employment opportunities, the results also show that the computed significance values of the relationship between equal employment opportunities and all dimensions of organisational commitment were negative. 
Hence, it is concluded that there is no significant relationship between equal employment opportunities and each dimension of organisational commitment. This might suggest that employees are not treated fairly. The manner in which they are treated determines the level of their commitment towards the organisation (Coetzee \& Botha, 2012, p. 9). Employees begin to seek for alternative job opportunities once they feel that they are not treated fairly (Van Dyk \& Coetzee, 2012). According to Coetzee and Botha (2012), fair treatment in the organisation includes giving workers autonomy, treating workers with respect, giving workers equal responsibility and having expectations of workers. The positive relationship between organisational commitment and equal employment opportunities as a critical HR management practices is dependent on perceived equity by employees (Peete, 2016, p. 23). Human resource policies and procedures should be observed consistently in the organisation to ensure perception of fairness (Coetzee et al., 2014; Dockel, 2003). It is therefore encouraged that equal and fair employment opportunities should be given to all employees despite their race, age, gender, beliefs and culture.

Benefits showed a significant positive with normative commitment. McMullen et al. (2009, p. 19) state that benefits, specifically healthcare benefits, are regarded as predictors of attracting and retaining talented employees, because competitors also provide employees benefits. Lack of healthcare benefits often results in employee dissatisfaction and increased turnover and absenteeism (Robbins \& De Cenzo, 2019, p. 314). Managers should offer solid employee benefits that attract and help to retain talented employees, such as employee wellness programmes. Recently, one of the important employee benefit trends is building a healthcare organisational culture as a manner to generate and retain a healthy, happy, active and productive workforce. Mabaso (2015, p. 31) agrees by affirming that benefits are significant characteristics that organisations use to motivate, attract and retain talented employees.

The results show a positive significant relationship between good and safe working conditions and affective and continuance commitment. In a workplace in which there are no adequate conditions, the motivation level of the employee decreases and this situation negatively affects the satisfaction of the employee (Ozdemir, 2009, p. 104). According to Mgiba (2015, p. 21), employees who perceive high limits in their working environment tend to be unhappy with their jobs. Coetzee and Botha (2012) agree by revealing that the way in which workers are treated determines the level of their commitment towards the organisation. Therefore, managers should create a conducive and safe work environment, which is satisfying for employees to perform their duties efficiently.

\section{Managerial implications}

Based on the findings of this study, it can be concluded that the organisation would likely improve employee commitment and attract and retain talented employees if they invest more in training and developing employees. This means that employees will meet the organisation's required current and future skills, in order to remain competitive in the market. Management should also appraise employees fairly. Furthermore, the organisation should hire qualified and talented employees because employees who are not qualified tend to underperform. The organisation should further offer motivating rewards such as 'employee of the month' recognition and solid employee benefits such as wellness programmes to keep employees active, happy, healthy and productive. It is noteworthy to highlight that a conducive and safe work environment is significantly important to the success of the organisation.

\section{Limitations of the study}

The results of this study should be considered with certain limitations in mind. Firstly, the study conducted a crosssectional research, which used a non-probability sampling technique. On account of the latter, the results cannot be generalised to the whole population. Secondly, because of the nature of the company, some participants seemed sensitive about revealing confidential company information. This could have resulted in inadequate responses to the questionnaire, which made it difficult to carry out the research. Lastly, the research was conducted in only one company, which makes it impossible to generalise the findings.

\section{Recommendations}

Similar studies could be conducted to investigate the impact of organisational commitment levels and the effectiveness of HR management practices at other organisations in South Africa such as municipalities, government departments, academic institutions and the hospitality sector. Similar studies could be conducted to investigate the relationship between organisational commitment, job satisfaction and the effectiveness of talent management.

\section{Conclusion}

The objective of this research was to investigate whether there was a significant positive relationship between organisational commitment levels and the effectiveness of HR management practices. The results show that rewards and equal work opportunities have a negative relationship with employees' levels of commitment. However, the findings show that there is a positive relationship between training and development, performance appraisal, staffing, information sharing, benefits and good workings, and commitment levels. These findings could assist managers to realise which $\mathrm{HR}$ management practices influence organisational commitment of employees particularly within the IT sector in South Africa. The results also show that there is a positive relationship between organisational commitment and demographics particularly gender, race, age, educational level and tenure. 


\section{Acknowledgements Competing interests}

The authors declare that they have no financial or personal relationships that may have inappropriately influenced them in writing this article.

\section{Authors' contributions}

L.N.S. initiated the project as part of his M Tech HRM degree. C.T.B. acted as a supervisor, and therefore involved from the conceptualisation of the project and L.P.D. acted as a cosupervisor. The authors wrote the article jointly as a team effort.

\section{Funding information}

This research received no specific grant from any funding agency in the public, commercial or not-for-profit sectors.

\section{Data availability}

Data sharing is not applicable to this article as no new data were created or analysed in this study.

\section{Disclaimer}

The views and opinions expressed in this article are those of the authors and do not necessarily reflect the official policy or position of any affiliated agency of the authors.

\section{References}

Anari, N.N. (2012). Teachers: Emotional intelligence, job satisfaction, and organisational commitment. Journal of Workplace Learning, 24(4), 256-269. https://doi.org/10.1108/13665621211223379

Armstrong, M. (2006). Performance management: Key strategies and guidelines (3rd edn.). London: Kogan Page.

Balgobind, P. (2007). The relationship between human resource management practices and organisational performance in the manufacturing sector of the beer industry in South Africa. MBA dissertation, Pretoria: University of Pretoria.

Becker, H.S. (1960). Notes on the concept of commitment. American Journal of Sociology, 6(2), 32-42. https://doi.org/10.1086/222820

Brock, M.E., \& Buckley, M.R. (2013). Human resource functioning in an information society: Practical suggestions and future implications. Public Personne Management, 42(2), 272-280. https://doi.org/10.1177/0091026013487047

Clinton-Baker, M. (2013). The relationship between career anchors, organisational commitment and turnover intention. M.Com dissertation, University of South Africa, Pretoria.

Coetzee, M., \& Botha, J. (2012). The languishment of employee commitment in the light of perceptions of fair treatment in the workplace. South African Journal of Human Resource Management, 10(2), 1-11. https://doi.org/10.4102/sajhrm.v10i2.436

Coetzee, M., \& Schreuder, D. (2010). Personnel psychology: An applied perspective. Cape Town: Oxford University Press.

Coetzee, M., Mitonga-Monga, J., \& Swart, B. (2014). Human resource practices as predictors of engineering staff's organisational commitment. South African Journal of Human Resource Management, 12(1), 1-9. https://doi.org/10.4102/sajhrm.v12i1.604

Coffie, R.B., Boateng, K.A., \& Coffie, F. (2018). Achieving organizational commitmen through HRM practices: The Ghanaian banking sector experience. Internationa Journal of Business and Management, 13(5), 171-184. https://doi.org/10.5539/ ijbm.v13n5p171

Cohen, A. (2007). Commitment before and after an evaluation and reconceptualization of organizational commitment. Human Resource Management Review, 17(3) 336-354. https://doi.org/10.1016/j.hrmr.2007.05.001

Döckel, A. (2003). The effect of retention factors on organisational commitment: An investigation of high technology employees. M.Com. dissertation, University of Pretoria, Pretoria.

Döckel, A., Basson, J.S., \& Coetzee, M. (2006). The effect of retention factors on organisational commitment: An investigation of high technology employees. South African Journal of Human Resource Management, 4(2), 20-28. https://doi. org/10.4102/sajhrm.v4i2.91
Farrell, A. (2013). An investigation into performance appraisal effectiveness from the perception of employees in an Irish consumer services company. MBA dissertation, National College of Ireland.

Fauzi, N.F.B., Ahmad, F., \& Gelaidan, H.M. (2013). The employee retention status in paddy and rice industry in Malaysia. Middle East Journal of Scientific Research, 18(5), 642-650.

Ferreira, N. (2012). Constructing a psychological career profile for staff retention. Doctoral dissertation. Pretoria: University of South Africa.

Field, A. (2009). Discovering statistics using SPSS (3rd edn.). London: Sage.

George, R.L. (2014). A critical investigation of recruitment and performance management in the import and export industry in Cape Town, South Africa. Doctoral dissertation, Cape Peninsula University of Technology.

Greenberg, J., \& Baron, R.A. (2003). Behaviour in organizations: understanding and managing the human side of work. Trenton: Prentice-Hall International.

Guchait, P. (2007). Human resource management practices and organizational commitment and intention to leave: The mediating role of perceived organizational support and psychological contracts. M.Sc thesis, Missouri-Columbia: University of Missouri-Columbia.

Hair, J.F., Black, W.C., Babin, B.J., \& Anderson, R.E. (2014). Multivariate data analysis. Harlow: Pearson.

Hassan, S., \& Mahmood, B. (2016). Relationship between human resource management practices and organizational commitment of employees: An empirical study of textile sector in Pakistan. International Journal of Academic Research in Accounting, Finance, and Management Sciences, 6(1), 23-28. https:// doi.org/10.6007/IJARAFMS/v6-i1/1952

Joiner, T.A., \& Bakalis, S. (2006). The antecedents of organisational commitment: The case of Australian casual academics. International Journal of Educational Management, 20(6), 439-452. https://doi.org/10.1108/09513540610683694

Kargar, M. (2012). Evaluation of organisational commitment of employees in university, case study: Islamic Azad University. Journal of Basic and Applied Scientific Research, 2(5), 5017-5021.

Khalili, A., \& Asmawi, A. (2012). Appraising the impact of gender differences on organizational commitment: Empirical evidence from a private SME in Iran. International Journal of Business and Management, 7(5), 100-110. https://doi. org/10.5539/ijbm.v7n5p100

Kola, M.I. (2012). Managing employment equity in higher education in South Africa. Doctoral thesis. Pretoria: University of South Africa.

Laka-Mathebula, M.R. (2004). Modelling the relationship between organisational commitment, leadership style, management practices and organisational trust. Doctoral dissertation, University of Pretoria.

Latchigadu, C.M. (2016). The relationship between organisational culture and organisational commitment. M.Com dissertation. Pretoria: University of South Africa.

Mabaso, M.C. (2015). The influence of rewards on talent attraction and retention at a further education and training college in Gauteng. M.Tech dissertation, Vaal University of Technology, Vanderbijlpark.

Mabaso, M.C. (2017). The influence of rewards on job satisfaction and organisational commitment among academic staff selected universities of technology in South Africa. Doctoral dissertation, Durban University of Technology, Durban.

Martin, A., \& Roodt, G. (2008). Perceptions of organizational commitment, job satisfaction and turnover intentions in a post-merger South African tertiary institution. South African Journal of Industrial Psychology, 43(1), 23-31. https:// doi.org/10.4102/sajip.v34i1.415

Martocchio, J.J. (2013). Strategic compensation: A human resource management approach (7th edn.). Upper Saddle River, NJ: Pearson.

Mathieu, J.E., \& Zajac, D.M. (1990). A review and meta-analysis of the antecedents, correlates and consequences of organisational commitment. Psychological Bulletin, 108(7), 171-194. https://doi.org/10.1037/0033-2909.108.2.171

Meyer, J.P., \& Allen, N.J. (1991). A three-component conceptualization of organizational commitment. Human Resource Management Review, 1(1), 61-89. https://doi. org/10.1016/1053-4822(91)90011-Z

Mgiba, S. (2015). Job satisfaction and the intention to quit by employees in a stee manufacturing company in Gauteng. M.Tech dissertation, Vaal University of Technology, Vanderbijlpark.

Mitonga-Monga, J., \& Flotman, A.P. (2017). Gender and work ethics culture as predictors of employees' organisational commitment. Journal of Contemporary Management, 14(1), 270-290.

Mrara, M.T. (2010). An investigation of turnover and retention factors of health professional employee within the Eastern Cape Department of Health. M.Com dissertation, Rhodes University, Grahamstown.

Muleya, D. (2017). Retention factors and employee organisational commitment at a higher education institution in South Africa. M.Com dissertation, University of Venda, Thohoyandou.

Naik, N.A. (2012). Organisational culture and organisational commitment in a consulting firm. M.Com. dissertation. Pretoria: University of South Africa.

Ndjama, J.D.N. (2015). Employees' perceptions of corporate social responsibility and the relationship with organisational commitment and intention to stay in a telecommunications company. M.Tech dissertation, Vaal University of Technology, Vanderbijlpark.

Nkomo, E. (2013). Motivation, work values, organisational commitment and job satisfaction: Age and generational cohort effects. M.Com. dissertation. Johannesburg: University of the Witwatersrand. 
Obeidat, B., Masa'deh, R., \& Abdallah, A. (2014). The relationships among human resource management practices, organizational commitment, and knowledge management management practices, organizational commitment, and knowledge management processes: A structural equation modelling approach. International Journo
Business and Management, 9(3), 9-26. https://doi.org/10.5539/ijbm.v9n3p9

Ozdemir, S. (2009). Factors influencing job satisfaction in Azerbaijan companies. Journal of Qafqaz, 1(26), 102-108.

Peete, M.B. (2016). Employees' job satisfaction, organisational commitment and intention to stay at an International Hotel in Lesotho. M.Tech dissertation, Vaal University of Technology, Vanderbijlpark.

Robbins, S.P., \& Decenzo, D.A. (2019). Fundamentals of human resource management (12th edn.). John Wiley.

Şendoğdu, A., Kocabacak, A., \& Güven, S. (2013). The relationship between human resource management practices and organizational commitment: A field study. Procedia Social and Behavioural Sciences, 99(6), 818-882. https://doi.org/10.1016/j. sbspro.2013.10.553

Shayo, A.F. (2013). The effects of performance appraisal system on employees' performance in the Tanzanian community radios: A case of selected radios in Dar es Salaam. MBA dissertation, Open University of Tanzania, Dar Es Salaam.

Swanepoel, B.J., Erasmus, B.J., Schenk, H.W., \& Tshilongamulenzhe, T. (2014). South African human resource management: Theory and practice (4th edn.). Cape Town: Juta.
Tan, C.L., \& Nasurdin, A.M. (2011). Human resource management practices and organizational innovation: Assessing the mediating role of knowledge management effectiveness. Electronic Journal of Knowledge Management, 9(2), 155-167.

Thabane, L.J. (2016). The effect of job satisfaction on the organisational commitment of administrators at a University in Gauteng. M.Tech dissertation, Vaal University of Technology.

Tojari, F., Esmaeilli, M.R., \& Majedi, N. (2013). The predictability of coaching efficacy on organisational commitment. European Journal of Experimental Biology, 3(6), 164-171.

Tsere, A.A. (2015). Impact of training to organizational commitment on government institutions: A case of ethics secretariat. MBA dissertation, Mzumbe University, Mzumbe.

Van Dyk, J. (2011). The relationship between organisational commitment, retention factors and perceived job embeddedness. M.Com dissertation, University of South Africa, Pretoria.

Van Dyk, J., \& Coetzee, M. (2012). Retention factors in relation to organisational commitment in medical and information technology services. South African Journal of Human Resource Management, 10(2), 77-79.

Wahn, J. (1998). Sex differences in the continuance component of organizational commitment. Group and Organization Management, 23(3), 256-267. https://doi. org/10.1177/1059601198233004 